ARTICLE

\title{
Second-personal theodicy: coming to know why God permits suffering by coming to know God himself
}

\author{
Dylan Balfour ${ }^{1}$
}

Received: 21 October 2019 / Accepted: 4 May 2020 / Published online: 9 May 2020

(c) The Author(s) 2020

\begin{abstract}
The popularity of theodicy over the past several decades has given rise to a countermovement, "anti-theodicy", which admonishes attempts at theodicy for various reasons. This paper examines one prominent anti-theodical objection: that it is hubristic, and attempts to form an approach to theodicy which evades this objection. To do so I draw from the work of Eleonore Stump, who provides a framework by which we can glean second-personal knowledge of God. From this knowledge, I argue that we can derive a theodicy which does not utilise the kind of analytic theorising antitheodicists accuse of intellectual hubris.
\end{abstract}

Keywords Theodicy $\cdot$ Problem of evil $\cdot$ Wright $\cdot$ Stump $\cdot$ Narrative $\cdot$ Job $\cdot$ Nonpropositional

\section{Introduction}

The popularity of theodicy, an attempt to find justifying reasons for God's permission of suffering, has grown substantially in academic philosophy over the past few decades. This trend has been spearheaded by eminent philosophers of religion such as John Hick, Alvin Plantinga, and Richard Swinburne. However, the prominence of the theodical project has also given rise to its dialectical counterweight, anti-theodicy. The anti-theodicy literature admonishes the practice of theodicy for a variety

Dylan Balfour

dylan.balfour@ed.ac.uk

1 The University of Edinburgh, Dugald Stewart Building, 3 Charles Street, Edinburgh EH8 9AD, UK 
of reasons. "The hubris of theodicy" section outlines one such reason, expounded by N.T Wright in his book Evil and the Justice of God (2006), namely, that theodicy is intellectually hubristic. ${ }^{1}$ Michael Rea, in a review of Wright's book (2008), proposes that the work of Eleonore Stump, which draws from biblical narrative and the concept of non-propositional knowledge, may provide a theodical methodology which evades Wright's accusations of hubris. The section "Stump's methodology" explicates Stump's theodical methodology, found in her work Wandering in Darkness, paying particular attention to her distinction between "Dominican" and "Franciscan", or non-propositional, knowledge. Stump believes that the study of biblical narratives can provide non-propositional, Franciscan knowledge of God's character, which can be utilised for theodicy. In the section, "Stump on biblical narrative" I present Stump's interpretation of the book of Job. Her interpretation is unique in that it contends that Job, despite his immense God-sanctioned suffering, comes to understand that God is nonetheless perfectly loving through a direct second-personal encounter with God. I am sceptical that Stump's third-personal account of Job's second-personal experience itself can grant the reader personal knowledge of God. However, it does provide a model by which we may come to have non-propositional knowledge of God, through experiencing God ourselves. Drawing from the work of Green and Quan (2012), in the section, "Coming to know God personally in Scripture" I outline how such experience may be possible through reading Scripture, which can mediate "shared attention" between the reader and God. Finally, in the sections "arriving at theodicy via personal knowledge" and "deriving propositions from second-personal experience" I formulate a non-propositional approach to theodicy, in which we derive a series of theodical propositions from this personal, experiential knowledge of God. In this way, we can arrive at a satisfying theodicy without inviting accusations of intellectual hubris.

\section{The hubris of theodicy}

I will start by expositing the objection that theodicy is hubristic. In his book Evil and the Justice of God (2006), the theologian N.T Wright presents a forceful formulation of this objection. The basis of his argument is the belief that humans are egregiously ill-equipped to "solve" the existence of suffering in God's creation. What makes us think that we are suitable arbiters of the morality of God's creation? This presumptuousness, Wright thinks, exhibits a hubristic immaturity characteristic of post-Enlightenment thinking. By merely attempting theodicy, we place ourselves in an unmerited 'position of moral superiority' $(2006,32)$ in which,

...we face the counter-question as to which bit of dry, clean ground we are standing on that we should look down from that height and pronounce on the

\footnotetext{
1 Another prominent strand of theodicy is that the practice of theodicy is intrinsically immoral. See Simpson (2009) and Trakakis (2008) for discussions. My approach to theodicy may also evade this criticism, though I won't pursue that line of thought in this paper.
} 
matter with such certainty. Dietrich Bonhoeffer declared that the primal sin of humanity consisted in putting the knowledge of good and evil before the knowledge of God... it serves as a warning to us not to pontificate with too much certainty about what God should and shouldn't have done (33).

he salient point here is that as humans we are invariably flawed, both morally and cognitively. We are impaired, it seems, to the extent that the project of theodicy cannot even get off the ground. In a critical review of Wright's book, the philosopher Michael Rea summarises Wright's view as the claim that theodicy can often 'reflect an overestimation of our cognitive abilities and an underestimation of the depths to which they have been infected by evil' $(2008,466)$. In Wright's allusion to Bonhoeffer, he implies that theodicy is a vestige of original sin; the theodicist is like Adam and Eve, pig-headedly caught up in their quest for knowledge-at the expense of their relationship with God. This is Wright's warning against presumptuous attempts to glean abstractified knowledge about God and his moral character. Instead, Wright thinks, we should take care to consider evil in its explicitly religious, rather than philosophical, context. Instead of pursuing knowledge externally to God, we can come to understand evil in creation through God. With this in mind, Wright spends the rest of his book discussing evil through a biblical lens, removing the problem of suffering from the hands of the analytic philosophers, and instead wrestling with it through the study of (what he believes to be) God's revealed word.

But need this methodology, involving the careful study of biblical narratives, be in opposition to the analytic philosophy of religion? Rea (2008) suggests not, proposing that the work of Eleonore Stump provides a methodology which, by incorporating the study of biblical narratives into a broader theodicy, evades Wright's charges that theodicy is necessarily hubristic and satisfies his desire for a biblical approach to theodicy. I will now outline her methodology.

\section{Stump's methodology}

Stump's theodical methodology is grounded on her conception of two typologies of knowledge: Dominican and Franciscan. I will detail these modes of knowledge before moving on to discuss the possible role of narrative in theodicy. I start with Stump's idea of Dominican knowledge, which can be broadly described as propositional knowledge, or "knowledge that". It is the knowledge that a given proposition is true or false. For example, Mary Berry knows, propositionally, that shortcrust pastry is made from butter and flour. In contrast, Franciscan knowledge encompasses those things which can be known but not articulated in conventional propositions. As such, Franciscan knowledge is a slippery concept to describe. But, as Efird and Worsley $(2017,209)$ note, we can intuit the nature of Franciscan knowledge via the use of thought experiments. Mary's Room ${ }^{2}$ is one used and adapted by Stump, which I will re-present.

\footnotetext{
2 The thought experiment was introduced by Frank Jackson in his 1982 paper 'Epiphenomenal Qualia' Philosophical Quarterly. 32, pp. 127-136.
} 
Consider Mary, an accomplished colour scientist. Mary knows everything there is to know about colour in terms of its scientifically-discoverable properties. That is, she knows all there is to know propositionally about colour, in the sense of 'knowledge that'. For example, she has knowledge that the wavelength of red light is 650 nanometres. ${ }^{3}$ In Stumpian terms, Mary has spent her life studying colour in a Dominican manner, through reading books and journal articles. But, crucially, Mary has also lived her whole life trapped in a colourless, black and white room. As such, she has never experienced colour, despite knowing everything that science has to say about it. The thought experiment proposes that were Mary to escape her room and see, say, a tomato, she would learn something new. She would not learn a new propositional fact, but rather what a tomato is like to see. On Stump's view, this nonpropositional knowledge of qualia is a form of Franciscan knowledge.

Another form of Franciscan knowledge, Stump thinks, is the knowledge of persons $(2010,52) .{ }^{4}$ Imagine that Mary, upon release from her grayscale prison, is greeted by her mother for the first time. Although Mary may have known everything there is to know about her mother propositionally, such as descriptions of her appearance and behavioural characteristics, Mary is exposed to a wealth of new second-personal knowledge through actually interacting with her mother. This conception of personal knowledge intuitively explains the way we speak about what is required to know someone as opposed to merely knowing about someone. For instance, I could know everything there is to know propositionally about teen heartthrob Harry Styles, for example his date of birth, ${ }^{5}$ hometown, ${ }^{6}$ and mother's maiden name, ${ }^{7}$ but if I were to claim that I know teen heartthrob Harry Styles, I would be mistaken. To know a person is to have had second-personal experience with them, and third-personal facts gleaned from a Wikipedia entry are not a substitute for this personal experience. As it is, I have Dominican knowledge of Harry Styles, but not Franciscan. ${ }^{8}$

It might be thought that the thought experiments involving Mary fail to capture the complexity of her distinctive form of life prior to her escape. In her black-andwhite room, Mary would have had a life completely alien to us. What does "red" or "mother" even mean to Mary prior to her experiencing them? An analogy might be drawn to those who live without certain conventional sensory abilities. In her diary, Helen Keller did not refrain from writing about objects of sight and hearing, even though she could not directly experience them. For instance, as a child she describes a cotton plant as having, 'pretty white and red flowers on it' $(2000,57) .{ }^{9}$ What could

\footnotetext{
3 Thanks, Google.

4 For alternative discussions on the nature of personal knowledge, see Lauer (2014) and Talbert (2015).

5 The 1st of February, 1994.

6 Redditch.

7 Cox.

8 Another form of Franciscan, non-propositional knowledge is so-called "knowledge-how". See Ryle (1945) for a seminal account of this kind of knowledge. I am grateful to an anonymous reviewer for pointing this out to me.

9 Thanks to an anonymous reviewer for pressing me on this, and for inviting me to consider those with different sensory abilities like Helen Keller.
} 
Helen Keller mean by these qualitative visual descriptions? In some sense she is using these words correctly and truthfully, but there is doubtless something lacking in her understanding of these visual concepts given her lack of phenomenal experience with them. This is the kind of understanding Mary has about concepts like "red". She possesses an intellectual understanding, but this does not amount to a complete understanding. When she finally experiences red, she gains a full, fluent understanding of the concept which includes its phenomenal character. Likewise, when she experiences her mother for the first time, she comes to fully understand who her mother is on top of her propositional knowledge about her.

It is with this epistemological framework that Stump's utilisation of narrative in her philosophical methodology can be understood. Narrative, Stump believes, is a rich source of Franciscan knowledge. Literary prose can elicit second-personal experiences, illuminating truths unavailable to conventional Dominican analysis. A proper use of narrative, then, goes beyond crude thought experiments which serve only to illustrate syllogistic premises, like, for example, trolley dilemmas in moral philosophy. Presenting narratives gives us access 'to a side of reality that can be captured better in narratives than in non-narrative prose' (29). Literature presents a more holistic, messy, and thus more truthful representation of the world, which can put flesh on the bones of analytic philosophy's skeletal frameworks.

\section{Stump on biblical narrative}

It is with this belief in literature's philosophical use that Stump embarks upon her explication of four biblical narratives, those of Job, Samson, Abraham, and Mary of Bethany, all of whom experience personal turmoil. I will focus on Stump's account of the book of Job, in which the eponymous character endures grievous suffering explicitly permitted by God but, according to Stump, nevertheless comes to understand that God is perfectly good through a second-personal encounter with Him. This account of Job serves as a platform to understand how we can arrive at theodicy through the non-propositional knowledge of God as a person, instead of propositional claims about God, in line with Michael Rea's suggestion.

\section{The book of Job}

Stump's account of Job is different to many other interpretations of the book. She does not see the story, as many other interpreters have done, as a treatise on the problem of evil. These interpreters read the book as a cautionary tale, warning against hubristic human attempts to understand God. N.T Wright appears to subscribe to this interpretation, seeing the book of Job as 'a monument to... the theological insistence that to "solve" the problem of evil in the present age is to belittle it' $(2004,42)$. There may be a grain of truth in these readings of Job-it would, for example, be easy (though perhaps unfair) to equate Job's useless comforters, who offer petty explanations of Job's sufferings instead of providing companionship, with modern theodicists. Stump does acknowledge that the book of Job proposes 
no simple solutions to the problem of evil, yet she also believes that Job receives an explanation for his suffering of a kind. For this "explanation" of evil we must, Stump thinks, examine the second-personal, Franciscan content of the book, paying attention to the parts which demonstrate the relationship between God and his creation. I will start by outlining Stump's account of the nature of Job's suffering, so that we know what needs to be "explained" in the first place.

\section{Job's suffering}

Stump describes Job's suffering as coming in two 'waves' brought about by Satan, which are, crucially, explicitly permitted by God $(2010,181)$. The first wave consists of the sudden loss of his wealth, servants, and the death of all of his children. These grievous losses elicit two kinds of suffering in Job. The first is an external suffering caused by the loss of property and wealth. The second, more profound suffering is that of an internal grief, caused by the loss of his children. This is a destruction of the things Job cares for most-which entails what Stump calls 'heart-cracking grief' $(2010,181)$. The second wave of suffering involves excruciating and unsightly boils all over Job's body. These not only cause Job unceasing physical pain but also disfigure him, alienating Job from himself and his community, and making him an isolated pariah.

Job is clearly an example of terrible suffering. It might be fair to label his ordeal an example of an horrendous evil, in the terminology of Marilyn McCord Adams, which she defines as 'evils the participation in which (that is, the doing or suffering of which) constitutes prima facie reason to doubt whether the participant's life could (given their inclusion in it) be a great good to him/her on the whole' (1999, 26). Certainly, Job seems to think so at one point: 'After this, Job opened his mouth and cursed the day of his birth' (Job 3:1). ${ }^{10}$ Undoubtedly, one could find examples of more egregious suffering, but the suffering Job endures nonetheless generates prima facie reason for the reader to doubt the goodness of God.

\section{Job's dialogue with God}

Stump believes Job comes to understand God's goodness and love for him, despite his suffering, through his personal dialogue with God at the end of the narrative. The context for this interaction is important—-throughout his ordeal Job is defiant in his suffering, insistent that the tragic events which befall him are unmerited. So confident is Job in his righteousness, that he requests a personal audience with God to argue his case and protest the perceived injustice of his torment (Job 13:3). In doing so, Job refuses to accept that the suffering he endures is morally condonable merely because it is permitted by God. He recognises the power and stature of God, but refuses to accept that might means right. This dissent against God display's Job's sincerity within the narrative, in stark opposition to his comforters' attempts to

10 All biblical references are NRSV. 
ingratiate themselves with God by making trivial excuses for Job's torment. ${ }^{11}$ Job's refusal to accept an artificial worldview purely to render his suffering intelligible is later vindicated by God's scolding of Job's comforters- 'My wrath has kindled against you and against your two friends; for you have not spoken of me what is right, as my servant Job has' (Job 42:7).

It is highly significant then, that, after Job's emotionally-charged accusations against God, God agrees to meet with Job face-to-face. The dialogue that takes place, in which Job ends up retracting his indictments against God and repents 'in dust and ashes' (Job 42:6), has been interpreted by many as an unsatisfactory resolution to the narrative. God does not offer a concise explanation or motivation for his treatment of Job, instead appearing to grandstand at length about the extent of his deific power and Job's comparative inconsequentiality. He recounts the process of creation, admonishing Job for his hubris in challenging him, 'where were you when I laid the foundations of the earth?' (38:4). However, Stump thinks this is more than confrontational grandstanding. Contained within God's speech to Job about creation is a host of parental and second-personal language, in which God seems to have a caring, personal relationship with even the inanimate elements of creation. He describes not only creating the clouds, but clothing them in garments (Job 38:9); He describes the ice as coming from His 'womb' (Job 38:29). Yes, these claims do demonstrate God's power. But, more significantly, they elucidate his relationship with creation. God presents himself not only as an all-powerful creator, but also as a loving parent and carer.

Even more important is the second-personal knowledge Job gains of God through seeing Him. Before he repents in dust and ashes, Job says, 'I had heard of you by the hearing of the ear, but now my eye sees you' (Job 42:5). Job is awed by coming into direct second-personal contact with God. And, like Mary the colour scientist meeting her mother for the first time, Job seems to learn something in the Franciscan mode by experiencing God. On Stump's interpretation, Job's repentance after God's speech is genuinely contrite. He does not simply supplicate in fear, but instead recognises his accusations against God were misguided. This is because, by engaging in dialogue with God, Job receives an explanation of his suffering beyond Dominican propositions. In coming to know God as a person, as only direct interaction can facilitate, Job comes to understand, Franciscanly, that God is loving and cares for him despite all he has endured. This does not mean that Job comes to understand his suffering. Instead, he comes to know that his suffering does not count as evidence against God's goodness by coming to know directly that God is good.

\section{Coming to know God personally in Scripture}

Through Stump's examination of the narrative of Job, we have come to see how a biblical character came to know God personally through their suffering. According to Stump's methodology, this examination gives us Franciscan, second-personal

11 This sincerity motivates Kant's proto-anti-theodicy, examined by Kivistö and Philström (2016). 
knowledge of God, through looking at how God interacts with his creation on a personal level. So, was Michael Rea correct that Stump's methodology leads us to nonpropositional, non-hubristic explanation of evil? I am not convinced. This is because Stump, instead of presenting the biblical narratives as narratives, provides detailed propositional interpretations of them. These interpretations of the narratives do contain second-personal content of a kind, but merely through third-personal accounts of second-personal interactions. ${ }^{12}$ These narrative accounts only facilitate thirdpersonal knowledge of God, giving us an insight into how God behaves, secondpersonally, to others. What we gain from examining the story of Job, for example, is that Job's second-personal experience of God granted him non-propositional knowledge of God's goodness. However, we, the reader, do not receive this knowledge ourselves, but rather a propositional account of Job's experience. Due to the nonpropositional nature of his understanding of God's character, it is esoteric and inaccessible to the reader. We know, in the Dominican mode, that Job comes to know that his indictments of God were unwarranted. But this Dominican knowledge- of Job's Franciscan knowledge-fails to meet Rea's call for a non-propositional, and thus non-hubristic, approach to theodicy. ${ }^{13}$

However, it gets us part of the way there. I believe Stump's account of Franciscan and Dominican knowledge provide the tools for a non-propositional theodicy. Although her presentation of Job's narrative fails to confer the Franciscan knowledge which she intends it to, her account of Job does serve as a kind of Franciscan case study - a biblical model for coming to directly know the goodness of God through second-personal encounter. What we need for a second-personal, non-propositional approach to theodicy is a philosophically coherent and theologically motivated account of how we can come to directly know God's goodness. ${ }^{14}$ And, once we come to directly know God's goodness and love, we can infer why God permits suffering. This section will provide such an account, drawing from the work of Green and Quan, who argue that Scripture can mediate second-personal encounters with God. ${ }^{15}$

\footnotetext{
12 Vitale's (2013) review of Wandering in Darkness shares this sentiment. He argues that the propositional detail of her narrative exegeses impedes the reader's ability to place themselves inside the narratives have the kind of Franciscan experience which Stump intends to provide.

${ }^{13}$ In Wandering in Darkness, Stump herself offers a relatively conventional propositional theodicy derived from Thomas Aquinas (371-417), in which suffering acts as a means to induce union between God and the sufferer. Because of this, in my view, Stump does not really utilise the theodical methodology which she proposes. The narratives end up serving as examples of her Thomistic theodicy, rather than arriving at theodicy through the narratives or Franciscan knowledge. Because of this, her theodicy becomes vulnerable to anti-theodial critique. On my theodicy, Job's narrative is also used for exemplary purposes, but as a template for how we can come to understand suffering through having personal, Franciscan knowledge of God.

${ }^{14}$ Rowe (1979) acknowledges the possibility of a theodicy along these lines, noting that the theist 'might appeal to certain aspects of religious experience, perhaps even his own religious experience' $(1979,340)$.

${ }^{15}$ One might be sceptical that we can even discuss the concept of Franciscan knowledge in the thirdpersonal, propositional mode. I think this scepticism is unwarranted, firstly because it is quite clear that we can intuit Franciscan knowledge through thought experiments (which operate propositionally), but also because there is a huge literature on the kinds of knowledge contained in the Franciscan typology (e.g. knowledge of persons, knowledge by acquaintance, knowledge-how, etc). We should be dubious of the claim that all this literature rests on a mistake.
} 


\section{Shared attention}

In their paper 'More than Inspired Propositions' (2012), Green and Quan postulate that the divinity of Scripture encompasses not only the traditional conception of divine inspiration - that the propositional content of Scripture is divinely inspiredbut also that we can come to experience God, second-personally, as readers of Scripture. The nature of this personal interaction is grounded in the concepts of 'dyadic' and 'triadic' attention (419), borrowed from developmental psychology. In short, dyadic attention consists of reciprocal attention between two persons focused on one another. Triadic attention consists of two persons sharing in attention on an external object. They present the following interaction as a demonstration of these types of attention:

First, the child looks the mother in the eye. Second, the child turns and points to a bright object. Third, the child looks back at the mother to see that she has followed the direction of the point. If the mother has cooperated with the pointing of the child, then the child and the mother had dyadic shared attention at stage one, and triadic shared attention at stage two. At stage three, the child checks to make sure that stage two has been successful, to make sure that the mother really is attending to the object with the infant (419).

God and Job shared both dyadic and triadic attention. Dyadic attention was instantiated in their face-to-face dialogue and, in God's invitations to Job to consider the wonder of his creation, they shared triadic attention. Like the child pointing to a bright object, God asks Job to join him in focusing his attention, through the use of rhetorical questions, on all the myriad ways in which God cares for the world. The triadic nature of this dialogue is more powerful for Job than a purely didactic monologue, as he attempts to grasp the enormousness and intricateness of God's creation with God himself as his guide. When God's speech ends, He and Job shared dyadic attention in which Job claimed to have "seen" God with his eyes, and repents, inspired by his new perception of God. This shared attention was instrumental in Job's acquisition of profound Franciscan knowledge of God.

\section{More than Inspired Propositions}

Green and Quan argue that we are capable of this kind of interaction with God through what they call a 'constitutive' reading of Scripture (426). On the constitutive reading, Scripture is seen as being actively presented by God to the reader as a means of attention sharing. By reading biblical texts as the work of a living and present God, one can engage in dyadic and triadic interaction with Him. If this seems implausible, consider an example of attention sharing through written texts.

Alex wins a private cooking lesson with Rachel Ray. He is deaf, so Rachel communicates with him using written notes. At a certain point in the lesson, she hands him a note that reads, "Consider the golden brown crust of the zucchini bake", at which point he attends with Rachel to the crust. He looks back 
at Rachel who smiles and holds out a note between them that reads, "You done good." (421).

Rachel Ray and Alex engage here in both dyadic and triadic attention, through the use of text. By presenting him with a personal instruction to consider his golden brown crust, Rachel Ray invites Alex to direct his attention to the same object that she is attending, in the same way that God invites Job to consider the totality of His creation. The notes Rachel writes personally to Alex constitute shared attention in a way that, had Alex read the exact same instructions in a Rachel Ray cookbook at home, would not have been the case. What this example shows is that even though the notes that Rachel Ray shares with Alex are propositional in term of content, sharing the notes is not a propositional speech act, so to speak. ${ }^{16}$ It is something else-an attempt to draw Alex's attention to both himself and his cooking alongside her. Green and Quan propose that Scripture can be read in the same way-as a personal note from God. Through biblical texts, God can draw our attention to him dyadically, to attend to Him, or triadically to consider, for example, one's pride (426).

An immediate objection might be raised that the reading of a static text, as Scripture is, is less like Alex being handed private notes from Rachel Ray, and more comparable to him reading the instructions for a zucchini bake in a Rachel Ray cookbook, where no shared attention takes place. The answer to this objection lies in the presumed divinity, or "revealed" nature of Scripture. As Green and Quan point out, there is plenty of theological support for viewing Scripture as a mediator for encounters with God (a view which has, in their view, typically been neglected by analytic philosophy). I won't give a detailed replication of the sources they invoke, but I will gesture towards a few to give a sense of the theological precedent for the constitutive reading of Scripture. Karl Barth, for example, holds Scripture to be, 'the place where we can expect to hear the voice of God' (1991, 78, cited in Green and Quan 2012, 417). The Catholic Church's Sacrosanctum Concilium claims, 'He is present in His word, since it is He Himself who speaks when the holy scriptures are read in the Church' (cited in Green and Quan 2012, 417). And Martin Luther: 'it is God himself who is speaking when it is God's Word which someone uses to comfort you... so remember that God himself is doing it' (Luther's Works 13:324, cited in Green and Quan 2012,418). These are just brief examples, but what we can glean from these sources is that holding God to be present in Scripture is hardly an unorthodox view. ${ }^{17}$ Of course, it would be question begging to simply assume the veracity of second-personal encounters through Scripture. ${ }^{18}$ But I am not assuming the veracity of such encounters here. Rather, all I am doing is establishing the philosophical coherency, as well as the theological motivation, of the constitutive reading of Scripture. Section five will address concerns that the importance of second-personal encounter to my theodicy is circular.

\footnotetext{
16 I am grateful to an anonymous reviewer for drawing me to consider this.

17 I invite readers to read Green and Quan (2012, 417-419) for a more thorough exploration of historical theological support for the constitutive reading of Scripture.

18 Thanks to an anonymous reviewer for drawing me to address this.
} 
So, although the constitutive reading of Scripture receives substantial theological support, more needs to be said about the mechanics of how God can be present in Scripture. Green and Quan provide an example - we can be drawn by God to read a certain part of Scripture through a kind of 'conscious prompting' (2012, 428). By following the prompting, one cooperates with God in focusing one's attention on a certain scriptural passage with God. In this case, Scripture facilitates a form of triadic attention sharing in which we glean not only the propositional content of Scripture, but also Franciscan knowledge of God through his presence in presenting Scripture. For example, if we were enduring suffering, God might direct our attention to His speech to Job; His illustrative examples of his care for creation would become directed, personally, at $u s$, in the same way they were for Job during his suffering. And, from this, we would obtain non-propositional knowledge of God's character beyond the mere propositional content of Scripture itself. A propositional text, when personally presented, becomes a mediator for shared attention and second-personal experience. Moreover, through this experience, we gain the ability to use "God" in the way Mary comes to be able to use "red". That is, fluently, with an understanding granted by Franciscan, not just Dominican, knowledge.

This is just one possible model for how Christian practice facilitates a secondpersonal encounter with God. There may be other plausible mediums for encounter with him, like prayer or worship. I won't go into more detail about other modes of second-personal encounter here. What matters for the second-personal theodicy is that there is at least one such medium by which we can encounter God. Green and Quan's constitutive reading of Scripture provides a philosophically coherent (and theologically informed) mode of second-personal encounter. This is an improvement on Stump's claim that the Biblical narratives themselves facilitate second-personal knowledge of God, and provides a mechanism by which the second-personal theodicy can get off the ground.

\section{Arriving at theodicy via personal knowledge}

This section ties the previous sections together in pursuit of a kind of second-personal, non-propositional theodicy which, unlike most theodicy, is unsusceptible to the anti-theodicists' charge of epistemological hubris. How does it do this? First, I will formulate the problem of suffering.

(A) There is suffering in the world.

(B) If suffering exists, and there is no morally justifiable reason for an omnipotent, omniscient, perfectly good God to permit suffering, then such a God could not exist.

(C) There is no morally justifiable reason for an omniscient, perfectly good God to permit suffering.

(D) Therefore, such a God could not exist.

I concur with Stump that premise (A) would only be rejected by 'the most naive or tendentious among us' (2010, 3). Typically, theodicists also accept (B), and argue 
for the denial of (C). By denying (C) the theodicist argues that there is a morally justifiable reason for God to allow suffering, usually by outlining a specific possible reason, which thus denies the truth of (D) - leaving open that such a God could exist. However, it is the work devoted to the denial of $(\mathrm{C})$, by the formulation of hypothetical God-justifying reasons, at which Wright's charge of intellectual hubris is levied. The second-personal theodicy which I put forward works from the other end-it denies (C) by denying (D):

Second-Personal Theodicy: By coming to know God personally, we come to know that a loving God does exist (and therefore could exist). From this we can infer that there must a morally justifiable reason that He permits suffering.

This takes the form of a modus tollens argument:

$$
\frac{R \rightarrow \neg E, E}{\therefore \neg R}
$$

${ }^{19}$ By coming to know God personally, we come to have a Franciscan understanding of his character. This Franciscan knowledge informs us of God's love and perfect goodness where Dominican propositions about his character fall short. And it gives us a legitimate reason to assert that God does have a justifiable reason to permit suffering, even if the reason itself is inaccessible to us. This non-propositional approach to theodicy bypasses the typical theodical debate which concerns Dominican propositions about God, such as his existence or moral characteristics, by starting from the affirmation of God's existence and perfection. This theodicy reflects the experience of Job, who came to the conclusion of God's perfect goodness despite his horrendous suffering, even though a propositional explanation eluded him.

The first and most obvious objection to this argument will be that it is questionbegging. Typically, the purpose of theodicy is to provide an argument for how the God of classical theism can exist in light of the tremendous amount of evil and suffering in the world. By starting from the assumption of God's existence and perfection, it looks like I am asserting what needs to be proved. However, I believe that if we grant the legitimacy of Franciscan knowledge, then my argument is valid. I would indeed be begging the question if I were merely asserting propositionally that God exists and is loving. However, if one accepts that we can come to have nonpropositional, Franciscan knowledge of God (through Scripture or other means), then no circular reasoning has been employed. This becomes clear if we consider an analogous case.

Suppose that you find yourself in an online argument with an internet conspiracist, who is trying to convince you that the Eiffel Tower does not exist. Imagine they present some crafty and surprisingly plausible reasons to think that the Eiffel Tower is non-existent (involving some sinister plot involving the French Tourist Board). If his claims were true, then the Eiffel Tower would be non-existent. You find yourself unable to provide a suitable rebuttal to his argument. But, before you admit defeat, you remember your holiday in Paris last year in which you went to the

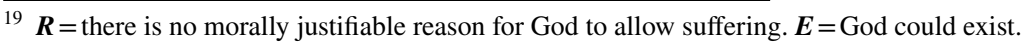


top of the Eiffel Tower. You did not hallucinate this trip-you even have a comedic photograph framed of you, looking like a giant, pretending to lean on the Tower. It would not be question begging if, in this online argument, you explain that you have visited the Eiffel Tower and experienced it for yourself. You might describe to the conspiracist what it was like to be at the top, and the amazing view you had of Paris. And thus, although you cannot refute his crafty conspiracy using Dominican propositions, you know his claims must be false-you have direct, experiential knowledge of what the Eiffel Tower is like, and can thus justify the propositional claim that it exists. This argument would have the exact same structure as the non-propositional theodicy:

$$
\frac{C \rightarrow \neg T, T}{\therefore \neg C}
$$

${ }^{20}$ Of course, the conspiracist need not accept your testimony. For all he knows, you could be deluded or lying. Your hilarious picture may be a photoshopped piece of propaganda disseminated by the French Tourist Board. The reason for this is that your knowledge of the Eiffel Tower is non-propositional and thus not directly transmittable to others. But its unpersuasiveness to the conspiracist does not invalidate your knowledge of the Eiffel Tower. In the same way, the validity of the second-personal theodicy does not depend on its persuasiveness to atheists. ${ }^{21}$ It is only important that the theodicy is incorporated into a consistent worldview for it to be successful-it need not persuade those who do not already believe in God. ${ }^{22}$

One might be concerned that this makes the second-personal approach insular. What's the purpose of a theodicy which doesn't speak to atheists, who are presumably likely to be persuaded by the argument from evil? ${ }^{23}$ A theodicy, after all, is intended to provide a reason to reject the argument from evil. There are two things to say to this. The first is to point out that the problem of evil is a deep concern for many theists. If my argument works, then the second-personal theodicy is a valuable resource for these theists - it serves as an invitation to seek an encounter with God and gain direct knowledge of his goodness. Moreover, the theodicy ratifies this knowledge as a rebuke to the problem of evil (at least for that particular theist) using the tools of analytic philosophy. This is valuable in itself. The second is that it still serves some purpose for the atheist, namely, in demonstrating that there are resources in the Christian faith to answer the problem of evil. This answer consists of a second-personal encounter with God which, of course, the atheist will deny is possible. Due to the second-personal approach of the theodicy, this will have to be as good an answer for the atheist as we can get-but it is far from a trivial answer.

\footnotetext{
${ }^{20} \boldsymbol{C}=$ the conspiracist's claims are true. $\boldsymbol{T}=$ the Eiffel Tower exists.

21 I do not mean to imply here that claiming that God does not exist is anywhere near as ridiculous as claiming that the Eiffel Tower does not exist-merely that Franciscan experiences are resistant to Dominican rebuttals.

${ }^{22}$ For a discussion of how testimony of personal religious experiences affects the warrant for religious belief for the experiencer and others, see Jay (2015).

23 I am grateful to an anonymous reviewer for raising this concern to me.
} 


\section{Deriving propositions from second-personal experience}

We need not stop at this second-personal knowledge of God's love, however. Recall that your first-personal experience with the Eiffel Tower grounded the propositional claim that the Eiffel Tower exists. This served to show that non-propositional knowledge can justify propositional claims. Likewise, starting with our second-personal knowledge of God, we can proceed to make some justified propositional inferences of reasons for why suffering is compatible with God's omniscience, omnipotence, and benevolence.

First, though, more needs to be said about the relationship between propositional and non-propositional knowledge. Some may be unconvinced by the assertion that non-propositional knowledge can ground propositional claims, or at least propositional claims about God. The Eiffel Tower example provides an intuitive illustration for how non-propositional Franciscan knowledge can justify a propositional claim that the object in question exists. However, it is less clear that personal knowledge of God, gleaned through the kind of shared attention described in the section, "Coming to know God personally in Scripture", can justify propositional claims about God. Regardless, I think there is a strong case to be made that it can. For starters, it seems clear that second-personal knowledge more generally can ground propositional claims. This is a point made by Talbert in her account of personal knowledge (2015). To illustrate how this might work, imagine that your friend is telling you about her grandfather's recent passing. While she is talking, you see her eyes well up and you experience a corresponding impulsion to comfort her. You have an awareness of her sadness, and this is a kind of personal, non-propositional knowledge; you know her sadness without necessarily cognising a propositional belief that she is sad. Yet, as Talbert explains, 'if someone were to ask me, or were I to reflect on the situation later I could easily express my knowledge in propositional form' (2015, 197-198). Here, our personal knowledge of our friend, gleaned through a secondpersonal encounter, can justify propositional beliefs and claims about her. Thus, personal knowledge looks like it can perform a justificatory role for at least some kinds of propositions.

Furthermore, we have good reason to extend this justificatory possibility to propositions about God. Through engaging in shared attention with him, we can come to have second-personal knowledge of his character, from which we can infer propositional knowledge about him. In a 2009 paper, Adam Green makes the case that shared attention with God can, for example, lead us to infer the claim that God is loving. ${ }^{24}$ Just as one might experience another person as loving, 'if they seek out an opportunity to be alone with one for no other reason than the sharing of the moment' (463), we can experience God as loving through the non-propositional demonstration of his love exhibited through his choosing to engage us in second-personal encounter.

\footnotetext{
${ }^{24}$ In this paper, Green looks specifically at how mystical experiences can facilitate shared attention, but what's relevant is his claims about how shared attention per se can justify inferences.
} 
This is not to say that the issue is cut and dried, but I hope to have provided a robust case for the claim that we can derive propositional knowledge from personal knowledge. Crucially, however, this is not to say that personal knowledge is not reducible to propositions. This is important to note, as I am going to make a series of propositional inferences, inspired by Stump's Wandering in Darkness (2010), which provide a theodicy derived from our second-personal knowledge of God. However, I want to emphasise that, in doing so, I am not claiming that our personal knowledge of God could consist of these propositions. If we glean Franciscan knowledge of God's character, then something will always be lost in transmitting this through propositions.

However, I am optimistic that personal knowledge of God, and particularly knowledge of God's love, can get us somewhere towards a non-hubristic theodicy. The next section is an attempt to do so. I won't offer a full defence of this theodicy, since doing so would be another project in itself. But, even if one takes issue with the particulars of this theodicy, the methodology I have articulated will still remain sound. What ultimately matters is that it is in principle possible to arrive at theodicy derived through personal knowledge of God, rather than engaging directly in the practice of theodicy in the hubristic, Dominican mode.

\section{Suffering and union}

The theodical propositions I will defend, which I believe are derivable from secondpersonal encounter with God, are as follows:

1. God is loving.

2. God loves us.

3. To love someone is both to desire the best for them and to desire union with them.

4. Suffering is a means of catalysing union with God.

5. Therefore, God permits suffering because it catalyses union with Him, which is the best thing for us.

Premise (1) is the conclusion we come to after experiencing God for ourselves. Once we have arrived at (1), premise (2) is a trivial inference. ${ }^{25}$ In coming to know God as loving, we simultaneously come to know that God loves us.

Premise (3), however, requires more explication. I take love, as Eleonore Stump does (who herself is led by Aquinas), to consist of two desires $(2010,91)$. The first is a desire for the good of the beloved; the second is a desire for union with the beloved. This raises the need for the explication of two further concepts: the good, and union. Stump, again following Aquinas, conceptualises the highest Good for a person as union with God. This personal relationship with God, the source of all good, 'constitutes both the flourishing and the greatness of the human person in the

\footnotetext{
${ }^{25}$ It also has substantial Scriptural support. The parental language in God's speech to Job is one example among many.
} 
union' (387). Moreover, cultivating union with God removes a person from the possibility of falling prey to the worst thing possible for a human being-eternal separation from God. So, one entailment of love's desire for the Good of the beloved, is a desire for that person to have union with God. But what exactly is union? Stump describes it as a combination of 'significant personal presence and mutual closeness' (127). Both persons in a relationship must have spent significant time in joint, dyadic attention. "Coming to know God personally in Scripture" section describes how this may be possible between humans and God. For closeness between two persons to obtain, both parties must be able to whole-heartedly desire union with that person (124). This entails the ordering of one's hierarchy of desires in pursuit of union. If I were to desire union with a person on a merely first-order level (to use Frankfurtian terminology), but desired the reverse on a second-order level, then I would never be able to fully be close to that person. As Stump says, a 'person alienated from himself [via conflicting hierarchical desires] cannot have someone else close to him' (125). For union to exist between a human and God, the human must orient her desires whole-heartedly towards God, or else the depth of union will be diminished. From this we can infer the following:

The best thing for us is union with God. Because God loves us, He desires union with us. For us to be in union with God, we must whole-heartedly desire union with Him.

Premise (4) claims that human suffering facilitates this whole-hearted union with God, which is the best thing for us, by affecting our will in such a way as to integrate our desire for union with God. This requires some justification. Stump points to a plethora of empirical psychological research which demonstrates a link between experiencing suffering and personal development-known in the literature as "adversarial" or "posttraumatic" growth (2010, 457-460). The research shows that suffering forces the sufferer to confront the trajectory of their life, and reconsider their desires and values. In this way, suffering presents an opportunity for the integration of the will. The sufferer faces a life-changing experience, conducive to spiritual and personal growth. As such, the sufferer can use their experience to integrate their will in pursuit of union with God and become open to a relationship with Him. Objectors will raise the point that suffering can often be disintegrative as opposed to integrative-sufferers are often defeated by their suffering, and left internally divided, and less capable of union. Stump's reply is that suffering presents whoever experiences with a choice. Suffering can be medicinal, but only insofar as the sufferer chooses to use it as an opportunity to reshape their life. Thus, suffering can lead to the disintegration of a person's will, but it is ultimately up to the sufferer how they choose to confront their suffering.

If premise (4) is accepted, then we have arrived at a theodicy derived from a foundation of personal Franciscan knowledge of God. God permits suffering because, ultimately, it is for our good. Yes, suffering may harm us, but it is to save us 
from greater harm. ${ }^{26}$ As Stump says, 'the greater harm warded off is the permanent absence of union with God, and the greater good provided is the increased degree of everlasting shared union with God' (2010, 394).

\section{A solution to hubristic theodicy?}

As claimed earlier, I believe that this second-personal theodicy successfully argues for the existence of morally justifiable reasons for God's allowing suffering without stumbling into the theodical pitfalls condemned by anti-theodicists. This approach to theodicy sheds the hubristic elements of conventional Dominican theodicy. Unlike Stump, who derives propositional conclusions from propositional exegesis, using analytic tools to bootstrap herself into knowledge of God, my theodical approach arrives at propositional conclusions through second-personal encounter with God. On this approach, knowledge of God is placed front-and-centre, evading Wright's anti-theodical accusation that theodicy '[puts] the knowledge of good and evil before the knowledge of God' (2006, 33).

It might be objected that the reason this non-propositional theodicy avoids the common failings of theodicy, is that it is not really a theodicy at all. Theodicies (or defences), seek to develop specific reasons and theories of value which excuse God from moral wrongdoing. By asserting merely that a God-justifying reason must exist, by coming to personal knowledge of God, the non-propositional theodicy arguably exists outside of theodical practice. It may sit closer to a position of sceptical theism, which claims that if there are any God-justifying reasons, they are beyond the capabilities of human cognition. Firstly, it does not matter much whether the non-propositional "theodicy" is labelled a theodicy or something else. ${ }^{27}$ Its intention is to justify the theist in claiming that God is good, and has morally justified reasons to permit suffering. I believe that "theodicy" is the most accurate term for this, although I may be wrong. If another label happens to be more perspicuous, then this non-propositional approach could be called a viable alternative to theodicy, but it would not affect the argument's strength. Secondly, this argument is not a form of sceptical theism, as it does not claim that knowledge of specific God-justifying reasons is out of human reach. It only claims that we can have Franciscan knowledge of God's goodness, from which we infer the existence of such reasons. It may also be the case that we can have specific knowledge of these reasons in the Dominican mode-the two approaches to theodicy do not conflict. However, I expect that the Franciscan approach will be more appealing to those who are dubious of substantial propositional knowledge of God, which includes sceptical theists.

\footnotetext{
${ }^{26}$ See Shiffrin (1999) for a well-argued, independent case for why of inflicting harm in order to save someone from greater harm is justifiable.

27 Some might think it a "defence", which merely seeks to prove the logical compatibility of evil and the existence of God, rather than establish a particularly convincing reason for God's permission of suffering.
} 


\section{Conclusion}

Many people claim to have had second-personal experiences of God, either directly or mediated by Scripture, which gives warrant to their religious beliefs. This paper has outlined, in "Stump's methodology", "Stump on biblical narrative", and "Coming to know God personally in Scripture" sections, how these experiences are theologically and philosophically coherent. The narrative of Job provides a biblical template for how a person in the midst of suffering can still know that God is benevolent, and has reasons to permit suffering. The concept of Franciscan knowledge explains how we can know God's goodness through personal experience of him. And Green and Quan provide a coherent account of how we can come to have this personal experience of God, through shared attention mediated by Scripture. Section five of this paper explained how, once we have gleaned this second-personal knowledge of God, we can be justified in making a claim of his lovingness in light of the existence of suffering. Moreover, we can derive a series of propositions from our knowledge of God's love and conclude that he permits suffering because, ultimately, it is for out good. And, because of the non-propositional foundations of this claim, this theodicy evades N.T Wright's charges of intellectual hubris.

This approach to theodicy will no doubt have little persuasive power for atheists, who will reject that we can come to have this personal knowledge of God-I concede that the second-personal theodicy has little use in apologetics. But, that has not been the intention of this paper. What matters is that the theist, when asked if God could have a morally justifiable reason to permit suffering, can answer yes; not because they know the reason, but because they know God.

Acknowledgements This paper is dedicated to David Efird, who supervised the writing of this paper and strongly shaped its argument. David passed away on the 9th of January, 2020. He was endlessly kind, generous, and a wonderful scholar. I would also like to thank Joshua Cockayne for helping me revise the paper, as well as an audience at the University of York who provided feedback on an earlier draft.

Open Access This article is licensed under a Creative Commons Attribution 4.0 International License, which permits use, sharing, adaptation, distribution and reproduction in any medium or format, as long as you give appropriate credit to the original author(s) and the source, provide a link to the Creative Commons licence, and indicate if changes were made. The images or other third party material in this article are included in the article's Creative Commons licence, unless indicated otherwise in a credit line to the material. If material is not included in the article's Creative Commons licence and your intended use is not permitted by statutory regulation or exceeds the permitted use, you will need to obtain permission directly from the copyright holder. To view a copy of this licence, visit http://creativecommons.org/licen ses/by/4.0/.

\section{References}

Adams, M. M. (1999). Horrendous evils and the goodness of God. New York: Cornell University Press. Barth, K. (1991). Homiletics. Louisville, KY: Westminster John Knox Press.

Efird, D., \& Worsley, D. A. (2017). What an apophaticist can know: Divine ineffability and the beatific vision. Philosophy and Theology, 29(2), 205-219. 
Green, A. (2009). Reading the mind of God (without Hebrew lessons): Alston, shared attention, and mystical experience. Religious Studies, 45, 455-470.

Green, A., \& Quan, K. A. (2012). More than Inspired Propositions. Faith and Philosophy, 29(4), 416-430.

Jackson, F. (1982). Epiphenomenal qualia. Philosophical Quarterly, 32, 127-136.

Jay, C. (2015). Testimony, belief, and non-doxastic faith: The Humean argument for religious fictionalism. Religious Studies, 52(2), 247-261.

Keller, H. (2000). The Story of My Life. [Online]. Retrieved April 9, 2020, from http://cbseacademic.nic. in/web_material/doc/The\%20Story\%20of\%20My\%20Life,\%20by\%20Helen\%20Keller.pdf.

Kivistö, S., \& Philström, S. (2016). Kantian anti-theodicy and job's sincerity. Philosophy and Literature, $40(2), 347-365$.

Lauer, D. (2014). What is it to know someone? Philosophical Topics, 42(1), 321-344.

Luther, M. (1958-1986). Luther's works. St Louis and Minneapolis: Concordia and Fortress.

Rea, M. (2008). Wright on theodicy. Philosophia Christi, 10(2), 461-470.

Rowe, W. (1979). The problem of evil and some varieties of atheism. American Philosophical Quarterly, 16(4), 335-341.

Ryle, G. (1945). Knowing-how and knowing that: The presidential address. Proceedings of the Aristotelian Society, 46, 1-16.

Shiffrin, S. V. (1999). Wrongful life, procreative responsibility, and the significance of harm. Legal Theory, $5,117-148$.

Simpson, R. M. (2009). Moral antitheodicy: Prospects and problems. International Journal for Philosophy of Religion, 65(3), 153-169.

Stump, E. (2010). Wandering in darkness. Oxford: OUP.

Talbert, B. M. (2015). Knowing other people: A second-person framework. Ratio, 28(2), 190-206.

Trakakis, N. (2008). Theodicy: The solution to the problem of evil, or part of the problem? Sophia, 47(2), 161-191.

Vitale, V. (2013). Wandering in darkness by Eleonore Stump. Reviewed in Mind, 122(488), 1193-1201.

Wright, N. T. (2006). Evil and the justice of God. London: SPCK.

Publisher's Note Springer Nature remains neutral with regard to jurisdictional claims in published maps and institutional affiliations. 